\title{
Groundwater governance in Asia: present state and barriers to implementation of good governance
}

\author{
TADASHI TANAKA
}

Department of International Affairs, University of Tsukuba, Ibaraki 305-8577, Japan tadashi@geoenv.tsukuba.ac.jp

\begin{abstract}
The present state of groundwater governance in Asia was reviewed. The main problem regarding groundwater resources in each Asian country is overexploitation, causing water level decline, land subsidence and salt water intrusion. For those groundwater hazards, many countries have established regulations such as laws and regulations as countermeasures. However, those laws and regulations are not the basic laws on groundwater resources, but only for countermeasures to prevent groundwater hazards. Common problems and barriers for implementing groundwater governance in Asian countries are that there is more than one institute with different and sometimes overlapping responsibilities in groundwater management. To overcome those conflicts among institutions and establishment of good governance, it is necessary to establish an agency in the government as one coordinate function reinforcing the direct coordination and facilitation of groundwater policymaking and management. As one such framework, the conceptual law called the Water Cycle Basic Law, which is under planning in Japan, is examined in this paper.
\end{abstract}

Key words groundwater governance; Asia; groundwater hazard; regulation; countermeasures; overlapping responsibility; conceptual law; one coordinate function; Water Cycle Basic Law

\section{PRESENT STATE OF GROUNDWATER GOVERNANCE IN ASIA}

The present state of groundwater governance was reviewed based mainly on the report published by the IGES (Institute for Global Environmental Strategies) in 2006. Table 1 shows the summary of the present state of regal aspect, reading institution and regulatory of groundwater governance in Asian countries. Regarding the legal status of groundwater, China, Indonesia and Vietnam are situated as public, Philippines is also public, Thailand is State-owned and Japan is private. In Thailand, no specific legal instrument exists in any law at the present, but in accordance with generally accepted principles of law and special legal provisions in various acts, the ownership of all water resources is vested in the State. In Japan, there are no provisions regarding the right of groundwater; in principal the land owners have a right of groundwater use. Bangladesh, Malaysia, Korea and Sri Lanka have not yet formulated to regulate ownership or the right of groundwater use (IGES 2006).

Table 1 Summary of the present state of regal aspect, reading institutions and regulatory of groundwater governance in Asian countries.

\begin{tabular}{|c|c|c|c|c|c|}
\hline Item & $\begin{array}{l}\text { Country } \\
\text { China }\end{array}$ & Indonesia & Thailand & Vietnam & Japan \\
\hline $\begin{array}{l}\text { Legal aspect of } \\
\mathrm{GW}^{1,2}\end{array}$ & Public & Public & State-owned & Public & Private \\
\hline $\begin{array}{l}\text { Leading } \\
\text { Institution of } \\
\text { GWM }\end{array}$ & $\begin{array}{l}\text { Municipal } \\
\text { Gov. }\end{array}$ & $\begin{array}{l}\text { Municipal/ } \\
\text { Regency Gov. }\end{array}$ & Dept. of GWR & $\begin{array}{l}\text { Municipal } \\
\text { Gov. }\end{array}$ & $\begin{array}{l}\text { Municipal } \\
\text { Gov. }\end{array}$ \\
\hline $\begin{array}{l}\text { Regulatory } \\
\text { (Laws/ } \\
\text { Regulations) }\end{array}$ & Temp. Regul. & $\begin{array}{l}\text { Act } \\
\text { no.11/1974, } \\
\text { WSs Act no.7/ } \\
\text { 2004, Regency } \\
\text { Regul. } \\
\text { Municipal } \\
\text { Gov. } \\
\text { Regul. }\end{array}$ & $\begin{array}{l}\text { GW Act/1977 } \\
\text { Amendment in } \\
2003\end{array}$ & & $\begin{array}{l}\text { Indust. Water } \\
\text { Law/1956 } \\
\text { Buil. Water } \\
\text { Law/1962 }\end{array}$ \\
\hline
\end{tabular}

1 Philippines is also public, 2 Bangladesh, Malaysia, Korea and Sri Lanka have not yet formulated to regulate ownership or the right of GW use. 
The leading institutions of groundwater management in each country are summarized as follows: In China the Municipal Government, in Indonesia the City or Regency with technical recommendations of Provincial Government, in Thailand the Department of Groundwater Resources, and in Japan the Municipal (Prefecture/City) Government.

The main problem regarding the groundwater resources in each Asian country except in Vietnam, is overexploitation, which causes water level decline, land subsidence and salt water intrusion. Figure 1 represents the Japanese experience of environmental consequences according to the excessive groundwater development during the high economic growth period in the 1960s. Figure 2 shows the land subsidence in urban areas of Asia regions. Although the occurrence time of the land subsidence is different in each region, depending on the economic development period of each country/region, the situation of groundwater hazards such as land subsidence caused by overexploitation of groundwater resource is similar, as can be seen in Fig. 2.

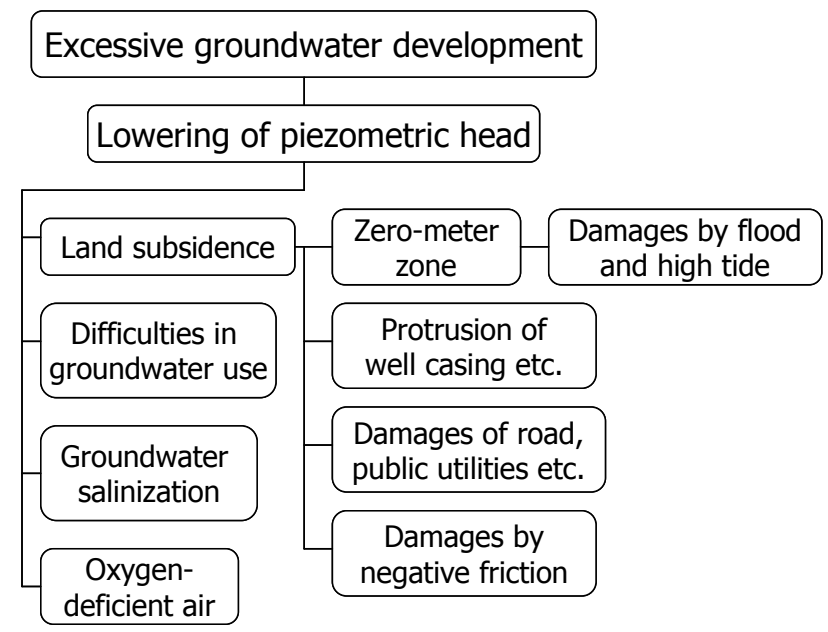

Fig. 1 Japanese experience of environmental consequences due to the excessive groundwater development (Kayane 1989).

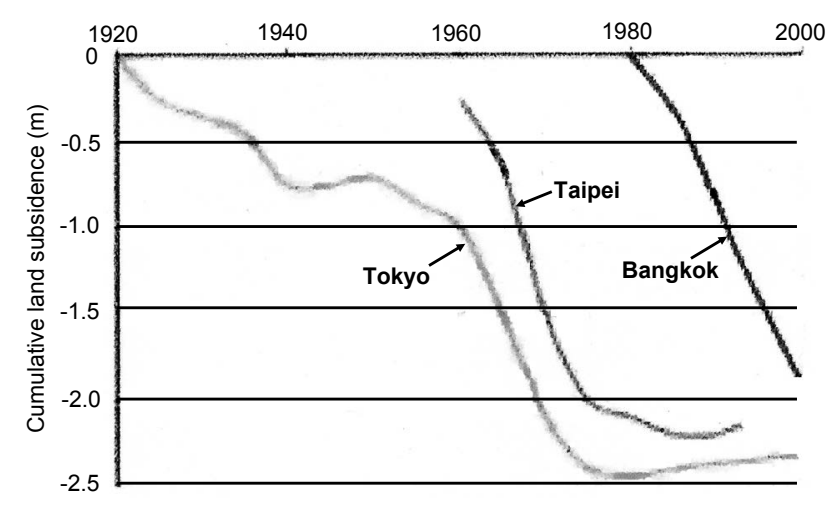

Fig. 2 Land subsidence in urban area of Asia regions (Taniguchi et al. 2006).

For those groundwater hazards, many countries have established laws and regulations as countermeasures: in China the temporary regulation on groundwater resources; in Indonesia Act no. 11/1974 and its amendment no. 7/2004 on water resources and regency and local government regulations; in Thailand the Groundwater Act in 1977 and its latest amendment in 2003; and in Japan the Industrial Water Law in 1956, Building Water Law in 1962 and many local ordinances. These laws and regulations, however, are not the principle/basic laws on groundwater resources, but are only for countermeasures to prevent the groundwater hazards occurring in each country. For sustainable use of groundwater resources, it is necessary to establish the conceptual law in each Asian country. 


\section{PROBLEMS AND BARRIERS FOR IMPLEMENTATION OF A GOOD GROUNDWATER GOVERNANCE IN ASIA}

Regional consultation for Asia and the Pacific Region of the new project on "Groundwater Governance: A Global Framework for Action" was held on 3-5 December 2012 in Shijiangzhuang, China. More than 70 scientists and specialists concerning groundwater issues in almost all Asian countries and the Pacific region participated in the meeting. The project is the result of the fruitful cooperation between UNESCO-IHP, the Global Environmental Facility (GEF), the FAO, the International Association of Hydrogeologists (IAH) and the World Bank. The overall project objective is to increase awareness of the importance of sound management of groundwater resources in preventing and reversing the global water crisis. The objectives of the regional consultations are: (1) the compilation of first-hand knowledge provided by direct local sources-groundwater experts, resource managers and actors in different areas, (2) the discussion about the different subjects that derive from the specific characteristics, challenges and priorities of the region based on case studies elaborated by national experts, and (3) to build partnerships amongst cross-sectional collaborating project agencies, stakeholders, decision-makers and specialists (UNESCO-IHP 2012).

A common problem and barrier identified through the meeting for implementation of the groundwater governance in Asian countries is that there is more than one institute with different, and sometimes overlapping, responsibilities in groundwater management. In Japan, six ministries/agencies relate to the management of groundwater resources. To overcome the conflictions between the ministries/agencies, the Council of Communication of related ministries/agencies of Japan was established in 1998. However, their activities are still not enough at the present time to overcome the overlapping responsibilities in groundwater management. Similar situations regarding the confliction among institutes were reported from China and the Philippines. For the establishment of good governance, an agency should be established and reenforced to direct coordination and facilitation of groundwater policy-making and implementation.

\section{THE CONCEPTUAL LAW UNDER PLANNING IN JAPAN}

Although the groundwater governance may be established in accordance with the physical, social, economic and cultural conditions in each country, the universal applicable framework of groundwater governance should be established based on a conceptual law for sustainable use of groundwater resources. As an example of such a conceptual law including the framework of direct coordination of water governance, the Japanese Government is now planning the establishment of the Water Cycle Basic Law (Japanese Parliament 2013) (After this manuscript was completed the draft of the Water Cycle Basic Law was approved by the Japanese Parliament on 27 March 2014; the Law was established on the same day). This planning basic law consists of 30 articles, as summarised in Table 2.

The purpose of the law, which mentions promotion of the policies on the water cycle as being integrated and in a body, is described in Article 1. The principal terms such as water cycle and sound water cycle are defined in Article 2. The five basic concepts, which are the importance of water cycle, shared natural resources, consideration of sound water cycle, integrated watershed management and international cooperation on water cycle, are set up in Article 3 as a special feature of the basic law. Articles 4 to 7 describe the responsibilities of the National and Municipal Governments. Although the contents of Articles 8 to 12 are omitted in Table 2, those are as follows: Article 8 is the cooperation and corporation among stakeholders, Article 9 the basic course of policies, Article 10 the water day, Article 11 the legislative measures and Article 12 the annual report. Article 13 mentions the establishment of the Water Cycle Basic Plan and Articles 14 to 21 describe the basic policies/countermeasures. Finally, Articles 22 to 30 make mention of the Water Cycle Policy Headquarters which is set up in the Cabinet as one coordinate function.

For proceeding the basic law effectively, setting up the basic concepts of the law is fundamentally important for awareness of the necessity and the framework of the law to all the stakeholders. Setting up the policy headquarters in the Cabinet is the first trial to overcome the conflicts among vertically connected administrations of ministry/agency. Another characteristic of 
Table 2 Summary of Article contents of the Water Cycle Basic Law under planning in Japan.

\begin{tabular}{ll}
\hline Article no. & Contents \\
\hline Article 1 & Purpose \\
Article 2 & Definition: Water cycle, sound of water cycle, etc. \\
Article 3 & Basic Concepts: \\
& 1. Important of water cycle, \\
& 2. Shared natural resources, \\
& 3. Consideration of sound water cycle, \\
& 4. Integrated watershed management, \\
& 5. International cooperation on water cycle.
\end{tabular}

Article 4-7

Article 8-12

Article 13

Article 14-21

Article 22-30

\section{Responsibility of National and Municipal Governments}

Omission

\section{Water Cycle Basic Plan}

Basic Policies/Countermeasures:

Ex. Water storage and recharge functions, cooperation of different stakeholders, fostering young talents, development of science and technology, international collaboration and cooperation, etc.

\section{Water Cycle Policy Headquarters (Setup in the Cabinet)}

Make a proposal of water cycle basic plan, integrated adjustment of policies/countermeasures in related Ministries/Agencies/Institutions:

One coordinate function

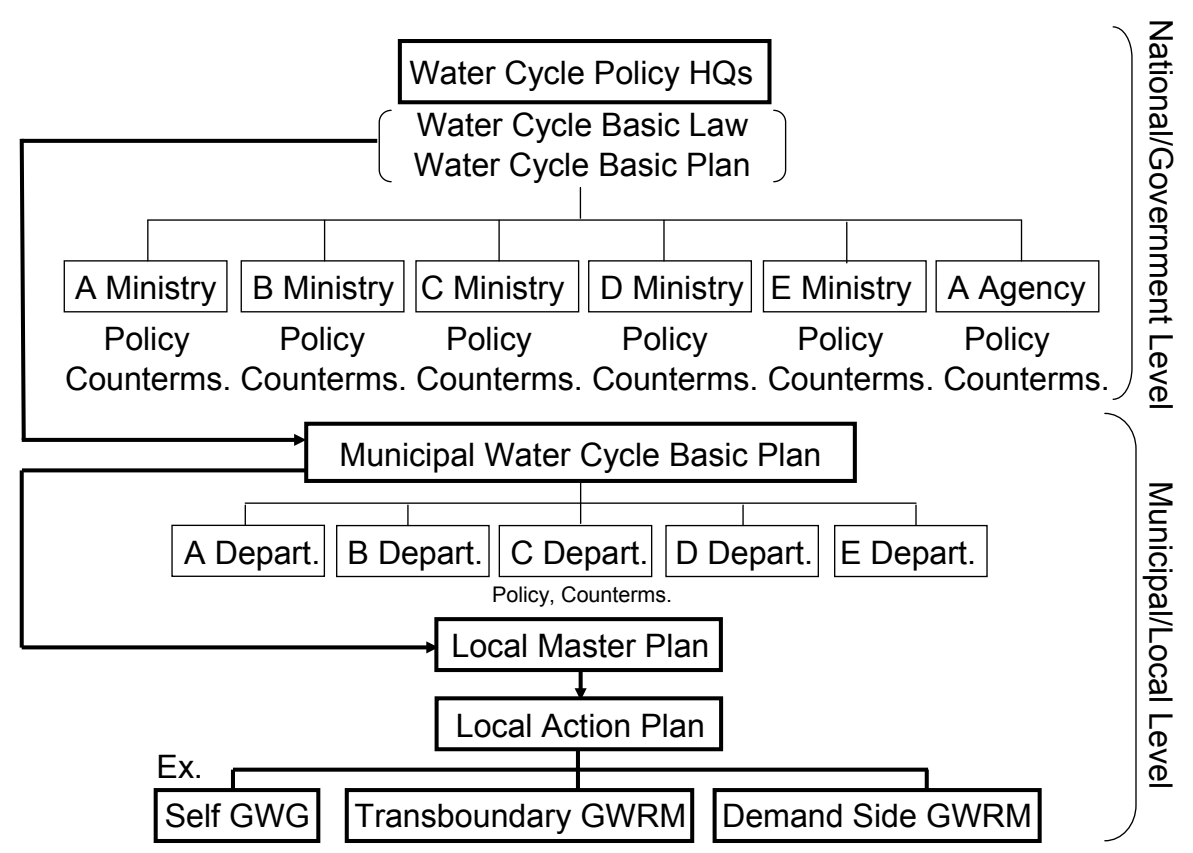

Fig. 3 Image of organizing structure corresponding to the Water Cycle Basic Law under planning in Japan.

the basic law is that it is formed from a 2-step framework of the basic law and the basic plan, as described in Article 13. This means that the basic law is a conceptual one and the basic plan is just the practical plan in accordance with the physical, social, economic and cultural conditions in each given region, because a water cycle or groundwater flow system is strongly site-specific.

Figure 3 shows the image of the corresponding organization structure of the Basic Law mentioned above. The organizing structure is from the national/government level and the municipal/local level. This two-level should not separate, but connects with the basic concept of the basic law. The municipal water cycle basic plan in the municipal/local level is the plan more realistically reflecting the natural, social and cultural conditions in the subject region. The local master plan means the relatively long-term plan in the period of 10 to tens of years and the local 
action plan is the short period plan of 3-5 years accomplishing the local master plan. Those plans will be checked and evaluated through the PDCA (Plan-Do-Check-Action) Cycle method.

At the present time, several countermeasures exist for preserving water resources in the framework of the ordinances in each municipal/local level in Japan, but they are not backed up by the legal base. On the contrary, the municipal water cycle basic plan in the framework of the Water Cycle Basic Law is just backed up by the legal base aspect, as indicated in Fig. 3.

Regarding the regulations related to the application of the law, it is established that the enforcement of the law is implementing within 3 months after the promulgation. For the time to produce a corresponding plan, as shown in Fig. 3, judging from the similar case of Japanese Environment Basic Law, which has a similar framework to the Water Cycle Basic Law and was introduced in 1993, it takes around one year for making the basic plan in the national/government level after enforcement of the law and then one to two years will be needed to produce the basic plan of the municipal/local level. So, the possible overall time required to reach the governance and management rules in the local level will be around 2-3 years after introducing the basic law. Although these response times may not be equal among countries, the organization structure represented in Fig. 3 might be applicable universally in each Asian country for carrying out the good groundwater governance as a framework for action.

\section{CONCLUDING REMARKS}

The main problem regarding the groundwater resources in each Asian country is the overexploitation causing water level decline, land subsidence and salt water intrusion. For those groundwater hazards, many countries have established the regulatory such as laws and regulations as countermeasures. Those laws and regulations, however, are not the principle/basic laws on groundwater resources, but only for countermeasures to prevent the groundwater hazards occurring in each country. As the legal aspect of groundwater resources, it is not necessary to be defined as merely public, but should be defined as a shared natural resource because a groundwater flow system is a strongly site specific one, controlled/affected by the physical, social, economic and cultural conditions in each country, even within a given country. Although the groundwater governance may be established in accordance with such conditions, the universal applicable groundwater governance should be established for sustainable use of groundwater resources and for the next generations. A common problem and barrier for implementation in the groundwater governance in Asian countries is that there is more than one institute that have different and sometimes overlapping responsibilities in groundwater management. For the establishment of good governance an agency should be established and reinforced to direct coordination and facilitation of groundwater policy-making and implementation. It is an effective way to introduce a conceptual law and corresponding basic plan including one coordinate function to adjust policies/countermeasures of related institutions for carrying out a good governance of groundwater resources. For such a law and its framework, the Water Cycle Basic Law under planning by Japanese Government provides useful idea/information, as described in the paper.

(After this manuscript was completed the Draft of the Water Cycle Basic Law was approved by the Japanese Parliament on 27 March 2014, and the Law has been established on the same day.)

\section{REFERENCES}

IGES (2006) Sustainable Groundwater Management in Asian Cities, A Summary Report of Research on Sustainable Water Management in Asia. IGES, 97 p.

Japanese Parliament (2013) Draft of the Water Cycle Basic Law. http://www.shugiin.go.jp/itdb_gian.nsf/html/ (19 June 2013). (in Japanese)

Kayane, I. (1989) Personal communication.

Taniguchi, M. et al. (2006) Affects of Human Activities Remained in Underground Environment of Urban Area. FR 2 Project, Research Institute for Humanity and Nature. (in Japanese)

UNESCO-IHP (2012) Information paper on GEF Project "Groundwater Governance: A Global Framework for Action" Regional Consultation for Asia and the Pacific Region. UNESCO-IHP, Division of Water Sciences, UNESCO HQ, Paris, 2p. 